\title{
AC 2004-7: USING ALUMNI NETWORKING TO TEACH TECHNICAL COMMUNICATION
}

\author{
Julie Sharp, Vanderbilt University
}


Session 2661

\title{
USING ALUMNI NETWORKING TO TEACH TECHNICAL COMMUNICATION
}

\author{
Julie E. Sharp \\ Vanderbilt University
}

\begin{abstract}
This paper reports on a pilot project integrating the Vanderbilt Engineering Alumni Council (EAC) mentoring initiative with the ES 210w Technical Communication course, a technical communication class for all engineering majors taken mostly by juniors and seniors. The purpose was to establish helpful networking opportunities for students while teaching them report writing skills. Students surveyed alumni and other professionals about technical communication tasks at work. The following components comprised this project: an alumnus guest speaker, introducing the project; the writing assignment given to the students; student groups' planning and gathering information from alumni, the group-written reports, students' post-assessment of the project, and a final alumni-sponsored luncheon meeting with alumni, students, the professor, and administrators. Survey results showed technical communication to be valuable and somewhat time-intensive in the workplace. Students and alumni both considered this project to be successful and recommended keeping it in the course with the students' rating being a 4.1 on a 5 -point scale.
\end{abstract}

\section{Introduction}

Bridging the gap between the engineering classroom and industry or "the real world" has been a goal for many engineering educators. To achieve it, some educators have simulated real engineering projects, ${ }^{1}$ encouraged students to contact alumni and other professionals, ${ }^{2}$ and set up mentoring programs. ${ }^{3-5}$ Alumni mentoring is one practice becoming more widely used, particularly with first-year engineering students. As Musiak et al. state, "Mentors help students get a better perspective on what the engineering profession is all about and what is expected of them to become engineers." ${ }^{6}$ This paper reports on a pilot project integrating the Vanderbilt Engineering Alumni Council (EAC) mentoring initiative with the ES 210w Technical Communication course.

Prior to this project, another alumni mentoring project at Vanderbilt Engineering School had already been tried with freshmen in the introductory course. Freshmen were encouraged, though not required, to contact members of the Engineering Alumni Council and to begin establishing a supportive relationship that could be continued throughout and beyond their college years. In this way, students could form a network that could be valuable as they entered the workforce. In assessing this project's results, the EAC determined that not enough freshmen had participated. The EAC, therefore, decided to try networking with older students who might be more interested since they were nearer to graduation and entering the workforce. The technical communication course for all engineering majors seemed to fit the requirements since mostly juniors and seniors 
take it. It had the added benefit of including job search communication, which fit the alumni's interest in providing advice about resumes, cover letters, and interviews.

In designing a way to incorporate this project into the class, the author believed that making the contact with alumni part of an assignment would be most productive. Consequently, the new group assignment was designed to do just that and replaced the previous semester's group project. In addition, the project offered the opportunity for students to learn from alumni about communication tasks at work and to determine if their mentors concurred with studies showing that good communication skills are essential to job success. ${ }^{7-8}$ Another advantage was that students could request sample documents from their mentors. As Norback et al. ${ }^{9}$ and Russell ${ }^{10}$ indicate, analyzing real world documents can be helpful in educating students about future communication tasks.

\section{The Assignment and Methodology}

The assignment required students to interview two professionals about communication tasks at work, to report results in a two-page individual report, and to summarize their group's data in a five-page group-written report. The assignment was presented at the beginning of the course as the first major assignment so that the mentoring relationship could be established early. Once the relationship was established, then students might be willing to initiate unrequired contact about other issues later. The purpose of the assignment was twofold:

(1) The instructor's purpose was to teach students report writing skills and the importance of technical communication in the workplace.

(2) The EAC's purpose was to provide a framework for networking and alumni assistance to bridge the gap between school and work and to encourage students to continue the mentoring relationship beyond the ES 210w requirement.

Students worked in groups of three or four. Each group developed a survey questionnaire designed to gather information on written and oral communication tasks performed by people in technical or managerial jobs. Eighteen alumni from various parts of the United States volunteered to be contacted by forty-three students through e-mail and/or phone. Most alumni preferred e-mail, but a few preferred telephone interviews. Each student was to contact one assigned EAC mentor and one other professional of the student's choice, someone working in their field of interest. Because the two-week turnaround time was relatively short, some alumni were travelling, and a few alumni were assigned four students, a concern was that some groups would not get sufficient alumni responses before the deadline. Having each student contact a second person allowed a greater chance of timely feedback from at least one respondent.

An EAC representative, one of two alumni liaisons, visited the two technical communication classes to describe the project from the mentors' point of view and to assign each student one alumnus to contact. His visit, a valuable component of this project, made the assignment concrete for the students and increased their interest.

Giving students specific, written details of the assignment, grading criteria, and procedures before they begin work is crucial to student achievement. ${ }^{11}$ With that tenet as a basis, the 
students received a written assignment sheet and the grading sheet for the group report before they began the project. For the grading sheet, a Likert scale was used to rate from 1 to 5 the following areas: audience awareness, organization, support, document design/visual appeal, and professional standards (writing style, language usage, grammar, and punctuation). The group report was the main report and was graded analytically with the grading sheet. The individual report was awarded points on an acceptable/unacceptable basis. Its purpose was to ensure that each student assessed his or her own data and contributed equally to the group report.

Student groups met in class during one period and outside of class as many times as needed to devise their questionnaires. As a starting point, they studied sample questionnaires from a previously used, similar assignment. Some questionnaires were designed to gather numerical ratings while some had short-answer questions. These are a few of the sample questions given to the students:

1. What kinds of the following communication tasks do you do at work: memos, letters, short reports, long reports, oral reports, briefings?

2. What are some of your reasons for communicating in these tasks and who is your audience?

3. How much time per week do you spend planning, writing, and editing documents?

4. How much time per week do you spend planning, creating, and presenting oral presentations, either formal or informal?

5. How important are communication tasks to your success at work?

6. Have you had any formal training or courses in technical communication, speech, or writing?

7. What do you wish you had known about communication tasks before you began your career?

8. What advice do you have for prospective engineers?

After analyzing the sample questionnaires, each group designed their own. Some groups designed questions to be answered with a Likert scale of 1 to 5 for easier tabulation, allowing space for comments. However, several groups chose short-answer questions only while some chose a combination of the two types. Here is an example of one group's questions: ${ }^{12}$

\section{ES 210W Group Project Questionnaire}

1. How important do you feel technical communication is in your occupation?

2. What is your educational background in communication?

3. What percentage of your time is spent on written/electronic communication?

4. What percentage of your time is spent on oral communication?

5. What are the most common types of communication that you perform? (i.e., memo, letter, etc.)

6. Who is your most common audience? (e.g., customer, supervisor, peer, etc.)

7. How dynamic must you be in your communications? Do you often have to tailor your communications to a wide range of audiences?

8. How important are writing skills in your occupation? (1-10 scale with 10 being most important)

9. How important are oral skills in your occupation? (1-10 scale with 10 being most important)

10. What percentage of your reports do you write individually? With at least one other person?

11. What percentage of your reports requires additional research? 
12. Does your organization have guidelines for written communications?

13. Are your reports usually revised? If so, by whom?

14. What software/medium do you use for communications?

15. How often do you use visuals in oral or written communications?

One group posted their questionnaire on a Web site inviting any engineer to respond; the online survey was automatically tabulated online. This survey netted sixteen responses for this threeperson group.

The group report had to contain the following parts:

- Introduction

- Description of subjects interviewed

- Procedure and methods

- Results and discussion

- Conclusions

- Recommendations (if any)

- Appendix (raw data, questionnaires, samples of company documents, and company guidelines for resumes and/or interviews)

Each student received copies of two survey reports to use as models. One was a student-written paper for a similar assignment and one was a professional article reporting survey results on a similar topic. ${ }^{13}$ Both were discussed in class, with one presented on an overhead transparency.

Near the end of the allotted two weeks, each student wrote the individual mini-report, using the same format required for the group report. Group members shared information from their reports and devised a strategy for compiling and reporting their information. The final result was the group paper reporting their compiled results. Shortly after all reports and rewrites were graded, students filled out an assessment form evaluating the project.

\section{Results of the Assignment}

All groups completed the assignment, gathered sufficient information for interpretation, and produced acceptable reports. Students' main findings were as expected: technical communication plays an important role in technical and managerial professions; and these professionals spend a significant portion of their work time communicating, some as much as 80 percent or more. In this study, depending on the respondents' occupations, different types of written and oral tasks were required. These findings correspond to research results from surveys of engineers, engineering technologists, and other professionals. ${ }^{14-18}$

Five of the twelve student groups chose the option to rewrite their reports, correcting all errors to earn back half their missed points. Most errors concerned organization, clarity, handling of figures and tables, and grammar/punctuation. The project allowed students to polish writing and data analysis skills as they learned information to prepare them for the workforce. Only one group was dysfunctional in that they could not agree on meeting times to merge the individual papers into the final group report. 
Students' comments throughout the assignment indicated that some were surprised at the alumni's responsiveness to their messages. Students also found surprising the results indicating that technical communication did affect job success and that professionals spent a significant amount of time on communication tasks.

An added benefit was that some respondents sent samples of their work, allowing students to see and analyze firsthand the kinds of communication tasks required in the workplace. Some examples included specifications, e-mail messages, a memo report, a research report, an application letter to participate in a workshop, and presentation visuals.

The alumni's comments reported by the EAC representative during the project indicated that alumni were pleased to communicate with the students and enjoyed the project. Some alumnistudent contact was made about other issues, including resumes, interviewing skills, and questions about the job hunt.

\begin{abstract}
Alumni Luncheon
The project was topped off a few weeks after the group report was completed by an alumnihosted luncheon for the students, attended by alumni, students, professors, and administrators. Twenty-seven of the forty-one students attended. The seating was arranged so that both alumni and students were seated at each table with some administrators and a few professors scattered among them. Conversation flowed well as the attendees received handouts reporting results of the student survey assessing the project. Asked beforehand to participate in a student panel to answer alumni questions about the project, five students were selected to represent the diversity in the two classes. In a lively interchange, they answered numerous questions from the audience for about twenty minutes.
\end{abstract}

\title{
Students' Evaluation of the Project
}

Besides anecdotal feedback, the success of the project was evaluated by students' answers to an evaluation form using a Likert scale. This assessment was taken a few days after students received the graded group reports and rewrites and before the alumni luncheon. This timing allowed the results to be reported at the luncheon. Table 1 presents the results, indicating students' perception that they did indeed learn about technical communication in the workplace. They recommended with a rating of 4.1/5.0 that the project should be repeated next semester. 
Table 1. Results of 39 Students' Assessment of the Workplace Communication/Mentoring Project Using a Scale of 1-5 with 1 strongly disagree and 5 strongly agree.

\begin{tabular}{|c|c|c|}
\hline & $\begin{array}{l}\text { Rating } \\
12345\end{array}$ & $\begin{array}{l}\text { Comments } \\
\text { (omitted here) }\end{array}$ \\
\hline $\begin{array}{l}\text { 1. I recommend that this project be included in ES } 210 \mathrm{w} \\
\text { next semester. }\end{array}$ & 4.1 & \\
\hline 2. I found this project to be helpful. & 3.9 & \\
\hline $\begin{array}{l}\text { 3. I learned useful or interesting information about } \\
\text { technical communication tasks at work. }\end{array}$ & 4.1 & \\
\hline $\begin{array}{l}\text { 4. The project affected my views in a positive way about } \\
\text { the significance of technical communication skills in the } \\
\text { workplace. }\end{array}$ & 4.2 & \\
\hline $\begin{array}{l}\text { 5. The contact with alumni was beneficial and provided a } \\
\text { good networking opportunity. }\end{array}$ & 3.7 & \\
\hline 6. I plan to contact one or more of these alumni again. & 3.0 & \\
\hline 7. Alumni responded in a timely fashion. & 4.2 & \\
\hline $\begin{array}{l}\text { 8. The time allotted for this assignment (after adjustment } \\
\text { was made to the syllabus) was sufficient. }\end{array}$ & 3.9 & \\
\hline 9. More time should be allotted for this assignment. & 2.7 & \\
\hline 10. Next time, students should contact more alumni. & 3.7 & \\
\hline
\end{tabular}

Interestingly, one of the lowest scores, 3.0/5.0 for item 6, indicated that not all students would initiate further contact with alumni. Comments from student panel members at the luncheon may have a bearing on this finding. They stated that they were hesitant about contacting their mentors once the project was over, fearing they might be a bother to the alumni. However, 14 of the 39 students responding rated item 6 as either a 4 or 5 . Nine rated item 6 either a 1 or 2 . Only two students wrote comments on the assessment form about planning further contact. One indicated he/she would "e-mail back the results of the survey." Another said:

I strongly hope so, as I don't want to abandon the relationships made,

but I'm not sure if it is very realistic. The alumni lunch is a great idea.

Waiting until after the luncheon to get student feedback may have yielded more information. Nevertheless, students seemed to think that more alumni should be contacted next semester when the assignment is repeated (item 10).

The score for item 5 about alumni contact being beneficial was lower than expected (3.7/5.0) although 21 of the 39 students rated this item either a 4 or 5 . Only one person rated it a 1 .

The alumni guest speaker and the instructor thought perhaps the two-week period allowed for the project was insufficient. Student ratings, however, indicated that the timing was about right. Conversely, several student comments on the feedback form indicated that some were dissatisfied with the time allowed. No one, however, recommended more than three weeks. 


\section{Conclusions and Future Plans}

Overall, the student feedback indicated that the project should be continued. One change, however, will be increasing the time allotted from two to three weeks because of alumni comments, a few student comments, and the instructor's feeling of being rushed. The assignment for the next semester will include the following components, the only other change being the timing of the student assessment:

- introduction of the project by an alumnus guest speaker

- the writing assignment (report on survey of technical communication tasks at work)

- students' information-gathering from alumni and other professionals (two mentors per student with six to eight mentors per student group)

- the final reports with instructor feedback, allowing for unacceptable reports to be rewritten

- an opportunity after the project is completed to meet with alumni attending Engineering Week activities

- $\quad$ student post-assessment with a written assessment form after the final opportunity to meet alumni

- $\quad$ alumni post-assessment

This project will be refined and continued in Spring 2004. Additional alumni assessment through a questionnaire is being collected now to get further input and to determine if a postcourse mentoring relationship has been established. The author's personal assessment is that this project, although time-consuming for the professor, was enjoyable and rewarding for all concerned.

\section{References}

1. Dyrud, M.A., " Communication and Civil Engineering: An Integrated Approach to Senior Projects," American Society for Engineering Education 2002 Conference Proceedings, CD ROM, 7 pp. Available online at http://www.asee.org/conferences/caps/document/2002-681_Paper.pdf.

2. Aanstoos, T.A., and S.P. Nichols, "Bridging the Gap: Student Perceptions of What the WorkPlace Demands," American Society for Engineering Education 2001 Conference Proceedings, CD ROM, 9 pp. Available online at http://www.asee.org/conferences/search/00091_2001.pdf.

3. Abrams, L.M., and Fentiman, A.W., "An Integrated Program to Recruit and Retain Women Engineering Students," American Society for Engineering Education 2002 Conference Proceedings, CD ROM, 7 pp. Available online at http://www.asee.org/conferences/caps/document2/2002-1799_Paper.pdf.

4. Grabiec, R. and T. Zern, "Alumni Mentoring and First Year Seminar: A Valuable Link," American Society for Engineering Education 2002 Conference Proceedings, CD ROM, 11 pp. Available online at http://www.asee.org/conferences/caps/document2/2002-1194_Paper.pdf.

5. Wadia-Fascetti, S., and P.G. Leventman, "E-Mentoring: A Longitudinal Approach to Mentoring Relationships for Women Pursuing Technical Careers," Journal of Engineering Education, July 2000, pp. 295-300. 
6. Musiak, R., et al., "The Total Learning Environment of our Freshman Engineering Students," American Society for Engineering Education 2003 Conference Proceedings, CD ROM, 7 pp. Available online at http://www.asee.org/conferences/caps/document2/2003-1564_Paper.pdf.

7. Lang, J.D., et al., "Industry Expectations of New Engineers: A Survey to Assist Curriculum Designers," Journal of Engineering Education, Vol. 88, No. 1 (January 1999), pp. 43-51.

8. Evans, D.L., et al., "Attributes of Engineering Graduates and Their Impact on Curriculum Design," Journal of Engineering Education, Vol. 82, No. 4 (October 1993), pp. 203-211.

9. Norback, J.S., et al., "Teaching Workplace Communication in Senior Design," Proceedings of the 2002 American Society for Engineering Education Annual Conference and Exposition, CD ROM, 8 pp. Available online at http://www.asee.org/conferences/caps/document/2002-462_Paper.pdf.

10. Russell, D.R., "Writing to Learn to Do: WAC, WWW, WAW--WOW!," Language and Learning Across the Disciplines, Vol. 2. No. 2 (September 1997), pp. 3-8. Available online at

http://wac.colostate.edu/llad/v2n2/russell.pdf.

11. Lee, V., "Relating Student Experience to Courses and the Curriculum," The Class Act (Spring 1998), Nashville, TN: Vanderbilt University Center for Teaching, pp. 3-4.

12. Abdul Malek, R.H., B.T. Donegan, E.H. Alexander, and D.I. George, "Group Research Project on Workplace Communication," unpublished report for ES 210w, Vanderbilt University, Nashville TN, Sept. 15, 2003.

13. Sharp, J.E., and T.D. Giorgio, "Combined Instruction: Chemical Engineering and Technical Communication Eleven Years Later," 1992 ASEE Annual Conference Proceedings, Vol. 2, pp. 1273-1276.

14. Ref. 13.

15. Barnum, C., and R. Fischer, "Engineering Technologists as Writers: Results of a Survey," Technical Communication, Vol. 31 (Second Quarter), 1984, pp. 9-11. Cited in Burnett, R. Technical Communication. 5th ed. Fort Worth TX: Harcourt College Publishers, 2001, pp. 5-6.

16. Anderson, P.V., "What Survey Research Tells Us about Writing at Work," Writing in Nonacademic Settings. Ed. Odell, L., and D. Goswami. New York: Guilford Press, 1985, pp. 3-83.

17. Sageev, P. and C.J. Romanowski. "A Message from Recent Engineering Graduates in the Workplace: Results of a Survey on Technical Communication Skills," Journal of Engineering Education," vol. 90, no. 4 (October 2001), pp. 685-693.

18. McGregor, H. and McGregor, C., "Documentation in the Australian Engineering Workplace," Australasian Journal of Engineering Education, Vol. 8, No. 1, 1998, pp. 11-22. Cited in McGregor, H., "Engineers at Work: Developing Communication Skills for Professional Practice," Society of Technical Communication Conference Proceedings, 2000. Available online at http://www.stc.org/confproceed/2000/PDFs/00037.PDF.

\section{Julie E. Sharp}

Julie E. Sharp is Associate Professor of the Practice of Technical Communication in the Vanderbilt Chemical Engineering Department. She teaches and co-ordinates technical communication courses for all engineering majors and co-teaches combined chemical engineering lab/technical communication courses. A communication consultant and active ASEE member, she conducts workshops on communication, teaching issues, and learning styles.

Proceedings of the 2004 American Society for Engineering Education Annual Conference \& Exposition Copyright (C) 2004, American Society for Engineering Education 